\title{
INTRODUCTION/INTRODUCCIÓN
}

\section{"Cross-border basins today and forever"}

\author{
Edith Kauffer, Carmen Maganda
}

\begin{abstract}
This note presents an account of transboundary basins on a global and regional scale throughout history. The authors introduce the special section on transboundary basins, presenting their constant increase and profound complexity. Regions $\mathcal{E}$ Cohesion has shown a permanent interest in this subject, from its first publications and, in particular, with the 2014 special issue that addressed different theoretical, methodological, and case studies in different continents. The three readings that make up this section address contemporary water border contexts and Mexico-U.S. policy where multi- and transdisciplinary challenges continue.
\end{abstract}

Keywords: binational cooperation, Mexico-United States, hydropolitics, transboundary basins, Transboundary Water Assessment Programme.

If universal geography remains the same as we know it today, it will still be common to share water resources between two or more countries in the future, though this does not signify shared management by default or similarity of scenarios.

The so-called transboundary basins are extremely heterogeneous in: size; type of actors; their agreements or legal regimes; management projects and water infrastructure; and their local, national, and international visibility. The large basins on an international scale, such as the Nile, Mekong, and Danube Rivers, stand out because of their size, the number of states involved, and their large management bodies. At the other extreme, there are the basins that remain unknown because: they are small in size, like the Krka River between Bosnia and Croatia; they have been forgotten by states, such as the Usumacinta River in Mexico, forgotten despite being 
the most extensive and abundant transboundary basin in the country; or there is no notable cooperation in terms of transboundary management, such as the Paz River between El Salvador and Guatemala.

The literature on the normative framework of international waters indicates that by transgressing the borders of nation-states, transboundary basins can become a challenge and even an inconvenience for them, especially for those who are not signatories of the 1997 Convention on the Law of Non-Navigational Uses of International Watercourses that became an instrument of international law in 2014. The existence of this international law, as well as the existence of legal guidelines for regional water policies including the perspective of transboundary basins, such as the United Nations Economic Commission's 1992 Helsinki Convention and the 2000/60 Water Framework Directive of the European Union, establish a water policy scheme for signatories and refer to a collaborative management scheme in their transboundary basins.

Under the sponsorship of international commissions and agencies, some transboundary basins, such as the Danube and the Senegal, have established specific agreements between all the actors of the different countries territorially involved, or only among a part of them (for example, in the Mekong and Nile). Likewise, there are transboundary basins without significant cooperative efforts due to old conflicts around borders such as the situation between Mexico and Guatemala in the six shared basins where, despite national conflict, local cross-border practices in water are notorious and dynamic. Finally, there are transboundary basins that refer to bilateral cooperation agreements, which are most developed in Latin America, including those between Mexico and the United States, which is the theme of this special section.

At present, transboundary basins are a universe of deep complexity, and this reality is related in the first place with their gradual increase. Since the publication of the special issue of Regions \& Cohesion in 2014, which addressed different theoretical and methodological issues and case studies of transboundary basins in different continents (Kauffer \& Medina, 2014), the number of such basins in the world has increased from 277 to 286 (Kauffer, in press; Transboundary Water Assessment Programme, 2016). A first contributing factor to this complexity is the formation of new states - such as South Sudan in 2011 - which has caused the multiplication of international borders and, therefore, the creation of new transboundary basins. For example, South Sudan's independence added a new entry to the list of participants in the cross-border basin of the Nile River, made up of ten states.

To this double quantitative dynamic for the increase of the number of transboundary basins and of state actors involved in their territories, it is 
fundamental to add a growing complexity of the sociopolitical, socioenvironmental, and sociocultural problems associated with their existence. We refer, among others, to the historical conditions linked to borders, and to transformation processes that affect water resources, such as hydraulic works, including the construction of dams, environmental deterioration, the quality and quantity of water, and more recently, the extension of traditional extractive processes such as mining, oil, and gas (Kauffer, 2018) in border areas in different parts of the world.

Consequently, research devoted to transboundary basins must necessarily integrate perspectives of analysis that include the complexities previously described. For example, there is a need to consider the political aspects of cross-border territories, where power relations are exercised at different scales between the various actors that come together in addition to the nation states (Kauffer, 2014): nongovernmental organizations, funding agencies, international organizations, and international cooperation organizations (Koff, 2016), basin organizations regardless of their origin, networks and alliances, academic groups, and above all, the local actors of the basins.

This special section honors the thematic diversity of transboundary basins with three valuable analytical contributions focusing on the U.S.Mexico border scenario that obeys, above all, the dynamic of binational relations with a plurality of actors and differentiated problems in the different basins of the same border. The article by Stephen Mumme links the legal issues of international law with cross-border social cohesion by questioning the quasi-constitutional status of some international water treaties in North America under temporal, substantive, and contextual criteria, using data from the Transboundary Freshwater Dispute Database of Oregon State University in a very original way. For their part, the study by Alfonso Andrés Cortez-Lara, José Luís Castro-Ruíz, and Vicente Sánchez-Munguía develops analysis of another aspect of social cohesion: the importance of collaboration among cross-border actors to address water scarcity in contexts of climate variability. With particular emphasis on adaptation strategies in the Mexican portion of the Colorado River Basin, the authors demonstrate the impact of social and institutional factors on the local and binational management of water.

As a geographical complement, the contribution of Gonzalo Hatch Kuri, José Joel Carrillo Rivera, and Rafael Álvarez Huizar addresses the other part of the Mexico-U.S. border with the analysis of the recent binational hydrogeological assessment of the San Pedro River Aquifer within the framework of the Transboundary Aquifer Assessment Program (TAAP). The authors argue that in order to achieve a comprehensive assessment of transboundary ground waters, and a conceptualization and 
systemic vision of the functioning of these waters, shared monitoring and the standardization and exchange of data for the taking and management of strategic decisions on this subject is necessary.

The three readings place us in contemporary contexts of the hydropolitical Mexico-U.S. border where the multi- and transdisciplinary analytical challenge remains. The social and political sciences should continue to question the status of international agreements and the social and institutional impacts on water management, but they can also take into account the dimensions and conditions that integrate, in a complementary manner, hydrological studies on surface and underground waters in transboundary basins for a more integrated and accurate approach.

Happy reading!

\section{REFERENCES}

Kauffer Michel, E. F. (2014). Conflits et coopération dans les bassins versants transfrontaliers en Amérique Centrale et au sud du Mexique: du Lempa à l'Usumacinta. Regions and Cohesion, 4(2), 30-53.

Kauffer Michel, E. F. (2018). Pensar el extractivismo en relación con el agua en América Latina: hacia la definición de un fenómeno sociopolítico contemporáneo multiforme. Sociedad y Ambiente, 6(16), 33-57.

Kauffer Michel, E. F. (Coord.) (in press). Introducción. Cuencas transfronterizas: la apertura de la presa del nacionalismo metodológico. In E.F. Kauffer Michel (coord) Cuencas transfronterizas: la apertura de la presa del nacionalismo metodológico. (pp. 15-44). México: Centro de Investigaciones y Estudios Superiores en Antropología Social.

Kauffer, E., \& Medina, L. (2014). Entre conflictos y cooperación. Regions and Cohesion, 4(2), 1-9.

Koff, H. (2016). «Cross-border environmental peace» as the interaction of regional norms and local power: Lessons from cross-regional analysis of water security debates. Revista de Paz y Conflictos, 9(2), 19-42.

Transboundary Water Assessment Programme (2016). TWAP project. Descargado de http://www.geftwap.org/twap-project

\section{Introducción}

\section{Cuencas transfronterizas hoy y siempre}

\section{Edith Kauffer, Carmen Maganda}

Resumen: Esta nota presenta un recuento de las cuencas transfronterizas a escala global y regional a través de la historia. Las autoras introducen la sección especial de cuencas transfronterizas exponiendo su constante aumento y su profunda complejidad. La revista Regiones $\mathcal{E}$ Cohesión ha 
demostrado un interés permanente por este tema, desde sus primeras publicaciones y en particular con el número especial de 2014 que abordó distintas problemáticas teóricas, metodológicas y estudios de caso de cuencas transfronterizas en diferentes continentes. Las tres lecturas que componen esta sección abordan contextos contemporáneos de la frontera hídrica y política México-Estados Unidos donde el reto multi- y transdisciplinario continúa vigente.

Palabras clave: cooperación binacional, cuencas transfronterizas, gestión hídrica, México-Estados Unidos, Transboundary Water Assessment Programme

\section{Introduction}

\section{“Les bassins versants transfrontaliers aujourd'hui et pour toujours"}

Résumé. Cette présentation aborde les bassins versants transfrontaliers à l'échelle globale et régionale à travers l'histoire. Les auteures introduisent la section spéciale sur les bassins transfrontaliers en signalant leur constante augmentation et leur profonde complexité. La revue Regions $\mathcal{E}$ Cohesion a démontré un intérêt permanent pour ce thème depuis ses premières parutions en particulier avec la publication du numéro spécial de 2014 qui a evoqué diverses problématiques théoriques, méthodologiques et des études de cas dans différents continents. Les trois lectures qui composent cette section spéciale se centrent sur les contextes contemporains de la frontière hydrique et politique entre le Mexique et les États-Unis où le défí multidisciplinaire et pluridisciplinaire est toujours d'actualité.

Mots clefs: bassins versants transfrontaliers, Mexique-Etats-Unis, coopération binationale, estion de l'eau, Transboundary Water Assessment Programme. 